\title{
Comparison of six commercial enzyme linked immunosorbent assays for detecting IgM antibodies against Toxoplasma gondii
}

\author{
C VERHOFSTEDE, L VAN RENTERGHEM, J PLUM Department of Medical Microbiology, \\ University Hospital, Gent, Belgium
}

SUMMARY To evaluate the usefulness of different commercial enzyme linked immunosorbent assays (ELISAs) for the detection of IgM antibodies against Toxoplasma gondii the results of six of these assays for a panel of 81 sera were compared. The following tests were selected: Toxoplasma gondii IgM ELISA (Clark Laboratories), Toxoplasma IgM EIA (Labsystems), Toxo-M EIA (Abbott), Toxonostika M (Organon), Toxo M Enzyme Immunoassay (Hybritech) and Platelia Toxo IgM (Diagnostics Pasteur). An antibody capture ELISA developed at our laboratory was used as the reference test. An IgM immunoblotting assay was also performed. Four (Toxaplasma IgM EIA, Tox-M EIA, Toxonostika M, and Platelia Toxo IgM) of the commercial IgM ELISAs gave a high sensitivity and a high specificity. Toxo-M EIA, Toxonostika M, Toxoplasma IgM EIA and the Toxo M Enzyme Immunoassay were too insensitive, and the Toxoplasma gondii IgM ELISA was both insensitive and unspecific. No remarkable differences were observed between the results of indirect or antibody capture ELISAs, and between the results of ELISAs performed with polyclonal or monoclonal antibodies.

Diagnosis of acquired Toxoplasma gondii infection is usually based on the serological demonstration of IgG or IgM antibodies. Since the first description of a microplate enzyme linked immunosorbent assay (ELISA) by Voller et al, the ELISA has become an increasingly popular procedure for the detection of $T$ gondii specific antibodies. ${ }^{1}$ The ELISA for IgG antibody detection is already well accepted in most routine laboratories. Commercial ELISAs for IgM antibody detection, on the other hand, have only recently become available. The development of an IgM ELISA has posed some problems, and the search for an improvement in the specificity and sensitivity of the technique has resulted in a broad range of different test systems: both indirect ELISAs and antibody capture ELISAs have been developed. Antibody capture ELISAs are performed with either polyclonal or monoclonal antibodies. ${ }^{2-9}$ This study aimed at evaluating the usefulness of different commercial ELISAs for IgM detection. The results of six of them for a panel of 81 sera were compared. An antibody capture ELISA developed at our laboratory was used as a reference test to select and group the tested sera. An immunoblotting assay for the detection of IgM antibodies was used an an additional technique in cases in which discordant ELISA results were found.

Accepted for publication 13 July 1989

\section{Material and methods}

COMMERCIAL TESTS

Toxoplasma gondii IgM ELISA (Clark Laboratories Inc., Jamestown, New York)

The principle of this test is based on an indirect solid phase enzyme immunoassay. The procedure is carried out in three basic reaction steps. Ninety six well $12 \times 8$ strip polystyrene microtitre plates are coated alternatively with toxoplasma antigen and control antigen. After the patient's serum has been incubated horseradish peroxidase conjugated anti-human IgM is added. Peroxidase activity is detected using o-phenylenediamine (OPD) and hydrogen peroxide. The colour intensity is determined in a spectrophotometer at $492 \mathrm{~nm}$. Control well absorbance is substracted from antigen well absorbance for each sample. Potential interference from such factors as rheumatoid factor are averted by treating serum samples with goat anti-human IgG before running the assay. The overall incubation time for this assay is one hour and 10 minutes.

Toxoplasma IgM EIA (Labsystems, Helsinki, Finland)

The principle of the Labsystems ELISA is similar to that of the Clark ELISA. Toxoplasma antigens are 
coated on the polystyrene surface of a 96-well $12 \times 8$ strip microtitre plate. After incubation of the patient's serum sample, alkaline phosphatase conjugated antihuman IgM is added. Phosphatase activity is detected using p-nitrophenylphosphate (PNPP). The colour intensity is determined at $405 \mathrm{~nm}$. The overall incubation time for this assay is two hours and $\mathbf{4 5}$ minutes. Serum samples are treated with rheumatoid factor absorbent purchased from Behringwerke (Marburg, West Germany) in order to minimise rheumatoid factor interference.

Toxo-M EIA (Abbott, North Chicago, Illinois) This is an ELISA based on an antibody capture principle. The patient's serum sample is incubated with a polystyrene bead coated with anti-human IgM. A complex of toxoplasma antigen, rabbit antitoxoplasma IgG, and horseradish peroxidase is then added to the bead. Peroxidase activity is detected using OPD and hydrogen peroxide. The overall incubation time of this assay is three and a half hours.

Toxonostika $M$ (Organon Technika, Boxtel, The Netherlands)

The principle of this test is similar to that of the Abbott ELISA but the Organon ELISA is performed in 96well $8 \times 12$ microtitre plates. The wells of the plate are coated with sheep antibodies to human IgM. After the patient's serum has been incubated a mixture of toxoplasma antigen and sheep antitoxoplasma antibodies, which have been labelled with horseradish peroxidase, is added. Peroxidase activity is detected using tetramethylbenzidine (TMB) and urea peroxide. Absorbances are read at $405 \mathrm{~nm}$. The overall incubation time is two and a half hours.

Toxo M Enzyme Immunoassay (Hybritech Europe, Liège, Belgium)

The principle of the Hybritech ELISA is similar to that of the Abbott ELISA. The patient's serum is incubated with a plastic bead coated with monoclonal antihuman IgM. A complex of toxoplasma antigen, antitoxoplasma IgG, and alkaline phosphatase is then added to the bead. Phosphatase activity is detected using PNPP. Absorbances are read at $405 \mathrm{~nm}$. The overall incubation time is two and half hours.

Platelia Toxo IgM (Diagnostics Pasteur, Marnes-laCoquette, France)

This ELISA is also based on an antibody capture principle. The wells of a 96-well $6 \times 16$ strip microtitre plate coated with anti-human IgM are incubated with patient's serum. A mixture of toxoplasma antigen and antitoxoplasma monoclonal antibody labelled with peroxidase is added to the wells. The presence of peroxidase is detected by the addition of OPD and hydrogen peroxide. The overall incubation time is three hours.

All tests were obtained commercially and performed by the same technician according to the manufacturer's instructions. For each kit all determinations were done in the same run.

\section{REFERENCE ELISA}

The antibody capture ELISA developed at our laboratory is performed as described by Duermeyer $e t$ al with slight modifications. ${ }^{10}$ Briefly, 96-well microtitre plates (Immunoplate I, Nunc, Roskilde, Denmark) are coated overnight with goat anti-human IgM antibodies (Tago Inc., Burlingame, California) at $2 \mu \mathrm{g}$ protein $/ \mathrm{ml}$ carbonate buffer, $\mathrm{pH} 9 \cdot 6$. After washing with phosphate buffered saline (PBS) containing $0.05 \%$ Tween -20 (PBS-T) a $1 / 200$ dilution in PBS-T of the sera to be tested is added to duplicate wells and incubated at room temperature for one hour. Plates are then washed with PBS-T. Toxoplasma antigen is diluted $1 / 200$ in PBS-T and is added to one of the wells. The other well is filled with PBS-T as a blank control. Plates are incubated for one hour at room temperature and then washed again. Rabbit antitoxoplasma serum $(1 / 100000$ in PBS-T) is added to all wells. The plates are washed after one hour, and goat anti-rabbit peroxidase conjugate (Tago) $(1 / 5000$ in PBS-T) is added and incubated at room temperature for one hour. The plates are washed again and the amount o bound enzyme is measured with OPD and hydrogen peroxide as the substrate. The reaction is stopped after 20 minutes by adding $4 \mathrm{~N} \mathrm{H}_{2} \mathrm{SO}_{4}$ and the optical density is read at $492 \mathrm{~nm}$. Blank control readings are substracted from the readings obtained with antigen. Reference positive and negative sera are tested on each plate to define the cut-off value.

\section{Toxoplasma antigen used in the reference ELISA}

Toxoplasma trofozoites are cultivated in human larynx carcinoma cells (Hep-2) as described previously." After passing through a $3 \mu \mathrm{m}$ pore size polycarbonate filter (Nucleopore Corporation, Pleasanton, California) to eliminate contaminating cells the purified organisms are pelleted $(2000 \times \mathrm{g}, 10$ minutes) and resuspended in distilled water to a concentration of $1 \times 10^{8}$ trofozoites $/ \mathrm{ml}$. This suspension is then sonicated five times for one minute at 50 watts, and to each $\mathrm{ml}$ of sonicate $30 \mu \mathrm{l} 37 \%$ formaldehyde is added. Preliminary tests have indicated that treating the antigen in this way leads to an important reduction of non-specific binding in the IgM-ELISA. The antigen preparation can be stored at $4^{\circ} \mathrm{C}$ for a period of at least six months.

IMMUNOBLOTTING ASSAY

An antigen preparation containing $2 \times 10^{8}$ purified 
Table 1 IgM results of six commercial ELISAs and reference ELISA for seven follow up sera from patient with acute $T$ gondii infection

\begin{tabular}{|c|c|c|c|c|c|c|c|}
\hline $\begin{array}{l}\text { Date of } \\
\text { blood collection }\end{array}$ & $\begin{array}{l}\text { Reference } \\
\text { ELISA }\end{array}$ & Abbott & Organon & Pasteur & Labsystems & Hybritech & $\begin{array}{l}\text { Clark } \\
\text { Laboratories }\end{array}$ \\
\hline $\begin{array}{l}24 / 10 / 85 \\
26 / 11 / 85 \\
06 / 02 / 86 \\
04 / 05 / 86 \\
02 / 01 / 87 \\
04 / 05 / 87 \\
26 / 11 / 87\end{array}$ & $\begin{array}{l}+ \\
+ \\
+ \\
+ \\
+ \\
- \\
-\end{array}$ & $\begin{array}{l}+ \\
+ \\
+ \\
+ \\
+ \\
+ \\
+\end{array}$ & $\begin{array}{l}+ \\
+ \\
+ \\
+ \\
+ \\
- \\
-\end{array}$ & $\begin{array}{l}+ \\
+ \\
+ \\
+ \\
+ \\
+ \\
+\end{array}$ & $\begin{array}{l}+ \\
+ \\
+ \\
+ \\
+ \\
+ \\
+\end{array}$ & $\begin{array}{l}+ \\
+ \\
+ \\
- \\
- \\
- \\
-\end{array}$ & $\begin{array}{l}+ \\
+ \\
+ \\
+ \\
- \\
- \\
-\end{array}$ \\
\hline
\end{tabular}

trophozoites/ml was electrophoresed in polyacrylamide slab gels using a discontinuous sodium dodecyl sulphate (SDS) buffer system as described by Laemmli with a $15 \%$ running gel and a $4 \cdot 75 \%$ stacking gel. ${ }^{12}$ Proteins were transferred from the SDS slab gel to a polyvinylidene difluoride membrane (Immobilon PVDF, Millipore, Bedford, Massachusetts) using the method of Towbin et al. ${ }^{13}$ After the transfer the PVDF membrane was soaked in PBS $+0: 5 \%$ Tween-20 (PBS-T) for one hour to saturate additional protein binding sites. Subsequently, the PVDF strips were incubated with a $1 / 400$ dilution of human serum in PBS-T containing $5 \%$ non-fat dry milk and thereafter with a 1/1000 dilution of alkaline phosphatase conjugated goat anti-human IgM (Sigma Chemical Co, St Louis, Missouri).

The alkaline phosphatase activity was detected by the method of Blake et al, using 5-bromo-4-chloroindolyl phosphate and nitro blue tetrazoliumchloride. ${ }^{14}$ According to Sharma et al, Potasman et al, and Herbink et al, sera with a clear reaction against the low molecular weight component ( \pm 6 kilodaltons) of toxoplasma were considered to be positive for the presence of specific IgM antibodies. ${ }^{15-17}$

\section{SERA}

A total of 81 sera sent to our laboratory to be tested for the presence of toxoplasma antibodies were used for serological comparison. The serum samples were classified in different series.

Series $A$ consisted of seven follow up sera from a single patient with an acute toxoplasma infection. The sera were taken from one week after onset of clinical symptoms, and over a period of two years.

Series $B$ consisted of 10 sera from patients with no evidence of a recent toxoplasmosis but with antiviral IgM antibodies detectable in their sera. This group included the serum of two patients with hepatitis A, one with rubella, one with measles, one with mumps, one with herpes simplex, two with cytomegalovirus and two with Epstein Barr virus IgM antibodies.

Series $C$ consisted of 10 sera from rheumatoid factor positive patients. Four of these patients also had antinuclear antibodies.
Series $D$ consisted of 28 sera from patients with toxoplasma specific IgM antibodies as defined in the reference ELISA. A recent toxoplasmosis in these patients was further confirmed by a rise in $\mathrm{IgG}$ in subsequent samples or the presence of clinical symptoms.

Series $E$ consisted of 14 sera from patients with lymphadenopathy but with no detectable IgM antibodies to toxoplasma in the reference ELISA.

Series $F$ consisted of 12 sera from pregnant women without clinical symptoms suggesting a recent infection, without detectable IgM antibodies in the reference ELISA, and for whom toxoplasma specific IgG titres remained constant for a period of over at least one month.

There was no significant difference between the age distribution and the amount of toxoplasma specific IgG antibodies for the patients in series B, C, E and F.

\section{Results}

Table 1 shows the ELISA results of the follow up sera from a recently infected patient (sera of series A). In three ELISAs (Abbott, Pasteur, and Labsystems) IgM antibodies were detected during the entire follow up period of two years. The ELISA of Hybritech, on the other hand, already gave negative results four to seven months after the first sample had been taken.

Table 2 summarises the results for the sera of series $B$ to F. None of the sera with antiviral IgM antibodies (series B) gave a positive result in any of the commercial ELISAs. In the reference ELISA one serum, containing hepatitis A virus IgM antibodies, was positive. This serum was clearly negative in immunoblotting.

With exception of the Hybritech ELISA, all tests gave positive results for one or two sera positive for rheumatoid factor (series $\mathrm{C}$ ). One of these positive patients gave a positive or equivocal result in four of the six commercial ELISAs (Abbott, Clark Laboratories, Labsystems, Pasteur), and in the reference ELISA. This serum was also positive by immunoblotting, suggesting that this patient still had low toxoplasma specific IgM antibody titres due to a recent 
Table 2 IgM results of six commercial ELISAs and of reference ELISA for 74 sera classified in five groups

\begin{tabular}{|c|c|c|c|c|c|c|c|}
\hline Series & $\begin{array}{l}\text { Reference } \\
\text { ELISA }\end{array}$ & Abbott & Organon & Pasteur & Labsystems & Hybritech & $\begin{array}{l}\text { Clark } \\
\text { Laboratories }\end{array}$ \\
\hline $\begin{array}{l}\text { B } \\
\text { C } \\
\text { D } \\
\text { E } \\
\text { F } \\
\text { Total }\end{array}$ & $\begin{array}{rrrr}+ & \pm & - \\
1 & 0 & 9 \\
0 & 1 & 9 \\
28 & 0 & 0 \\
0 & 0 & 14 \\
0 & 0 & 12 \\
29 & 1 & 44\end{array}$ & $\begin{array}{rrr}+ & \pm & - \\
0 & 0 & 10 \\
1 & 0 & 9 \\
28 & 0 & 0 \\
0 & 0 & 14 \\
1 & 1 & 10 \\
30 & 1 & 43\end{array}$ & $\begin{array}{rr}+ & - \\
0 & 10 \\
2 & 8 \\
28 & 0 \\
0 & 14 \\
0 & 12 \\
30 & 44\end{array}$ & $\begin{array}{rrr}+ & \pm & - \\
0 & 0 & 10 \\
0 & 1 & 9 \\
28 & 0 & 0 \\
0 & 1 & 13 \\
1 & 2 & 9 \\
29 & 4 & 41\end{array}$ & $\begin{array}{rrr}+ & \pm & - \\
0 & 0 & 10 \\
0 & 1 & 9 \\
28 & 0 & 0 \\
0 & 0 & 14 \\
0 & 4 & 8 \\
28 & 5 & 41\end{array}$ & $\begin{array}{rrr}+ & - \\
0 & 10 \\
0 & 10 \\
19 & 9 \\
0 & 14 \\
0 & 12 \\
19 & 55\end{array}$ & $\begin{array}{rrr}+ & \pm & - \\
0 & 0 & 10 \\
1 & 1 & 8 \\
25 & 0 & 3 \\
1 & 0 & 13 \\
4 & 0 & 8 \\
31 & 1 & 42\end{array}$ \\
\hline \multicolumn{2}{|c|}{$\begin{array}{l}\% \text { Specificity } \\
\% \text { Sensitivity }\end{array}$} & $\begin{array}{r}96 \\
100\end{array}$ & $\begin{array}{l}96 \\
97\end{array}$ & $\begin{array}{r}91 \\
100\end{array}$ & $\begin{array}{r}94 \\
100\end{array}$ & $\begin{array}{r}100 \\
74\end{array}$ & $\begin{array}{l}87 \\
91\end{array}$ \\
\hline
\end{tabular}

+ (positive), - (negative), \pm (doubtful).

The specificity and sensitivity of the commercial ELISAs compared with the reference ELISA were calculated as follows: $\%$ specificity $=$ (true negative/true negative + false positive results) $\times 100 ; \%$ sensitivity $=$ (true positive/true positive + false negative results) $\times 100$; true negative results = negative results in reference ELISA; true positive results = positive results in reference ELISA

One exception was made in the interpretation of true negative and true positive results: all the sera with antiviral IgM antibodies (series B) were considered to be negative.

infection. In the Organon ELISA two other patients positive for rheumatoid factor were reported positive. One of these patients was also positive in the Clark Laboratories ELISA. None of these patients was found to be positive by immunoblotting.

All the 28 sera from patients with a recent toxoplasmosis were found to be positive by immunoblotting and in four of the six commercial ELISAs (Abbott, Labsystems, Organon, Pasteur). The ELISAs of Hybritech and Clark Laboratories, on the other hand, only detected antibodies in, respectively, 19 and 25 of these sera.

All the 14 sera from patients with lymphadenopathy but with a negative result in the reference ELISA (sera of series $\mathrm{E}$ ), were also found to be negative in four of the six commercial ELISAs (Abbott, Hybritech, Labsystems, and Organon). The Pasteur ELISA gave a weakly positive result for one patient. Another patient was clearly found to be positive in the Clark Laboratories ELISA. These patients were found to be negative by immunoblotting.

Only two of the six commercial ELISAs reported as negative all of the 12 sera from pregnant women who had no indications of a recent infection and were found to be negative in the reference ELISA (series F).
In the four other tests positive or equivocal results were found. The ELISA results and immunoblotting results of series $\mathrm{F}$ are summarised in table 3 .

\section{Discussion}

The number of available commercial ELISA tests for the detection of toxoplasma specific IgM antibodies has increased considerably in recent years. To evaluate the usefulness of some of these commercial tests we compared the results of six of them for 81 carefullye selected sera. For the selection of sera an antibody-? capture ELISA developed at our laboratory was used as the reference test.

The studies of Sharma et al, Potasman et al, and Herbrink et al, have shown that recognition of a 6 kilodalton antigen in immunoblotting is highly correlated with detection of IgM antitoxoplasma antibodies in ELISA. ${ }^{15-17}$ An immunoblotting assay was therefore performed as an additional control test. Detailed studies concerning the diagnostic importance of immunoblotting compared with ELISA are, however, not yet available.

The overall agreement between four of the six

Table 3 Summary of IgM results of six commercial ELISAs and of immunoblotting assay for 12 pregnant women without clinical symptoms of recent $T$ gondii infection

\begin{tabular}{|c|c|c|c|c|c|c|c|}
\hline $\begin{array}{l}\text { No of } \\
\text { patients }\end{array}$ & Abbott & Organon & Pasteur & Labsystems & Hybritech & $\begin{array}{l}\text { Clark } \\
\text { Laboratories }\end{array}$ & Immunoblotting \\
\hline 4 & - & - & - & - & - & - & - \\
\hline 4 & - & - & - & - & - & + & - \\
\hline 1 & - & - & - & \pm & - & - & - \\
\hline 1 & - & - & \pm & $\overline{ \pm}$ & - & - & - \\
\hline$i$ & \pm & - & \pm & \pm & - & - & + \\
\hline 1 & $\bar{t}$ & - & $\bar{t}$ & \pm & - & - & + \\
\hline
\end{tabular}

+ (positive), - (negative), \pm (doubtful). 
commercial ELISAs (Abbott, Labsystems, Organon, and Pasteur), and between these tests and the reference ELISA was good. No remarkable differences were observed between the results of indirect ELISAs (Labsystems, Clark Laboratories) or antibody capture ELISAs, between the results of ELISAs performed with monoclonal (Hybritech, Pasteur) or polyclonal antibodies, or between the ELISAs performed on coated beads (Abbott, Hybritech) or in microtitre plates. The Clark Laboratories ELISA was the most rapid test (one hour and 10 minutes of incubation), the ELISA of Abbott was the most time consuming (three and a half hours of incubation). All six assays had a comparable handling ease.

Commercial IgM ELISAs were able to detect antibodies for either a long (Abbott, Labsystems, Pasteur) or a short (Hybritech, Clark Laboratories) period after a recent $T$ gondii infection, reflecting a higher or lower sensitivity of the test. This observation might indicate that a positive result in tests with a lower sensitivity correlates better with the recent stage of infection and that these tests are therefore more useful for the diagnosis of acute toxoplasmosis. One must be aware, however, of the fact that large individual variations in IgM response can exist and that a recent $T$ gondii infection can be accompanied by either a high or a low IgM response. ${ }^{918}$ The use of tests with a low sensitivity may mean that diagnosis can be -missed in those patients in whom IgM production is low.

Only the ELISAs of Abbott, Labsystems, Organon and Pasteur detected antibodies in all of the 28 sera from patients with confirmed acute infection. With the Clark Laboratories ELISA and the ELISA of Hybritech the diagnosis was missed in respectively three and nine of them, again reflecting the lower sensitivity of the latter tests.

Only the ELISAs of Abbott, Organon, and Hybritech did not give false positive results in the group of 36 patients with no evidence of a recent $T$ gondii infection (series B, E, and F). Two of these patients, with a positive result in the immunoblotting assay, were assumed to possess low titres of IgM antibodies at rest. False positive or doubtful results were common in the Clark Laboratories ELISA (five of 36), but were also seen in the Labsystems ELISA (two of 36), and that of Pasteur (two of 36).

False positive results were more common in the group of pregnant women than in the series of patients with adenopathy or with antiviral IgM antibodies. The reason for this discrepancy in the number of false positive results is unclear.

The presence of rheumatoid factor is seen as one of the most important sources of false positive results in the IgM detection systems. Interference of rheumatoid factor in the indirect ELISA without pre-treatment of the sera has been clearly shown. ${ }^{1920}$ The presence of rheumatoid factor interference in the antibody capture ELISA is still a matter of controversy. ${ }^{269}$ In our study only the Organon ELISA, which is an antibody capture ELISA, showed pronounced rheumatoid factor interference. These findings contrast with the results of Joynson $e t$ al, who found rheumatoid factor interference in the Abbott ELISA but not in the test of Organon. ${ }^{21}$ Interference with antiviral IgM antibodies was not demonstrable in any of the commercial ELISAs.

In conclusion, the IgM ELISAs of Abbott, Labsystems, and Pasteur have a high sensitivity and a high specificity, although in the ELISAs of Labsystems and Pasteur false positive results cannot be ruled out completely. The Organon ELISA can also be seen as a useful test, although it is less sensitive and the user has to be aware of possible rheumatoid factor interference. We found that the Hybritech ELISA is too insensitive and that the Clark Laboratories ELISA is both insensitive and unspecific.

\section{References}

1 Voller A, Bidwell DE, Bartlett A, Fleck DG, Perkins M, Oladehin B. A microplate enzyme-immunoassay for Toxoplasma antibody. J Clin Pathol 1976;29:150-3.

2 Briantais MJ, Grangeot-Keros L, Pillot J. Specificity and sensitivity of the IgM capture immunoassay: studies of possible factors inducing false positive or false negative results. $J$ Virol Methods 1984;9:15-26.

3 Cesbron JY, Capron A, Ovlaque G, Santoro F. Use of a monoclonal antibody in a double-sandwich ELISA for detection of IgM antibodies to Toxoplasma gondii major surface protein (P30). J Immunol Methods 1985;83:151-8.

4 Duermeyer W, Wielaard F, Van Gruythuysen H, Swinkels J. Enzyme-linked immunosorbent assay for detection of immunoglobulin $\mathrm{M}$ antibodies against Toxoplasma gondii. J Clin Microbiol 1980;12:805-6.

5 Franco EL, Walls KW, Sulzer AJ. Reverse enzyme immunoassay for detection of specific anti-Toxoplasma immunoglobulin $\mathbf{M}$ antibodies. J Clin Microbiol 1981;13:859-4.

6 Tomasi J-P, Schlit AF, Stadtbaeder S. Rapid double-sandwich enzyme-linked immunosorbent assay for detection of human immunoglobulin $\mathbf{M}$ anti-Toxoplasma gondii antibodies. J Clin Microbiol 1986;24:849-50.

7 Naot Y, Remington JS. An enzyme-linked immunosorbent assay for detection of IgM antibodies to Toxoplasma gondii: use for diagnosis of acute acquired toxoplasmosis. J Infect Dis 1980; 142:757-66.

8 Pouletty P, Pinon JM, Garcia-Gonzalez M, et al. An anti-human immunoglobulin $\mathbf{M}$ monoclonal antibody for detection of antibodies to Toxoplasma gondii. Eur J Clin Microbiol 1985;3: 510-5.

9 Wielaard F, Van Gruythuysen H, Duermeyer W, et al. Diagnosis of acute toxoplasmosis by an enzyme immunoassay for specific immunoglobulin M antibodies. J Clin Microbiol 1983;17:981-7.

10 Duermeyer W, Van Der Veen J. Specific detection of IgM antibodies by ELISA applied in Hepatitis A. Lancet 1978;ii: 684-5.

11 Verhofstede C, Sabbe L, Van Renterghem L. Ability of enzymelinked immunosorbent assays to detect early immunoglobulin G antibodies to Toxoplasma gondii. Eur J Clin Microbiol 1987; 6:147-51. 
12 Laemmli UK. Cleavage of structural proteins during the assembly of the head of bacteriophage T4. Nature 1970;227:680-5.

13 Towbin H, Staehelin T, Gordon J. Electrophoretic transfer of proteins from polyacrylamide gels to nitrocellulose sheets: procedure and some applications. Proc Natl Acad Sci USA 1979;76:4350-4.

14 Blake MS, Johnston KH, Russell-Jones GL, Gotschlich EC. A rapid, sensitive method for detection of alkaline phosphataseconjugated anti-antibody on western blots. Analyt Biochem 1984;136:175-9.

15 Sharma SD, Mullenax J, Araujo FG, Erlich HA, Remington. JS. Western blot analysis of the antigens of Toxoplasma gondii recognized by human IgM and IgG antibodies. J Immunol 1983; 131:977-83.

16 Potasman I, Araujo FG, Desmonts G, Remington JS. Analysis of Toxoplasma gondii antigens recognized by human sera obtained before and after acute infection. $J$ Infect Dis 1986; 154:650-7.

17 Herbink P, Van Loon AM, Rotmans JP, Van Knapen F, Van Dijk WC. Interlaboratory evaluation of indirect enzyme-linked immunosorbent assay, antibody capture enzyme-linked immunosorbent assay, and immunoblotting for detection of immunoglobulin $\mathbf{M}$ antibodies to Toxoplasma gondii. $J$ Clin Microbiol 1987;25:100-5.

18 Naot Y, Guptill DR, Remington JS. Duration of IgM antibodies to Toxoplasma gondii after acute acquired toxoplasmosis. J Infect Dis 1982;145:770.

$19 \mathrm{Knez}$ V, Stewart JA, Ziegler DW. Cytomegalovirus specific IgM and IgG response in cytomegalovirus infected human fibroblasts. J Immunol 1976;116:772-7.

20 Vejtorp $M$. The interference of IgM rheumatoid factor in enzymelinked immunosorbent assays of Rubella IgM and IgG antibodies. J Virol Methods 1980;1:1-9.

21 Joynson DHM, Payne RA, Balfour AH, Prestage ES, Fleck DG, Chessum BS. Evaluation of five commercial enzyme linked immunosorbent assay kits for toxoplasma specific IgM antibody. J Clin Pathol 1989;42:653-7.

Requests for reprints to: Dr C Verhofstede, Department of Medical Microbiology, University Hospital, De Pintelaan 185, 9000 Gent, Belgium. 